\title{
Assessment of the Impacts of Foreign Direct Investment and Interest Rate on the Growth of Nigerian Economy
}

\author{
Mukolu M.O, Otalu.J.A and Awosusi C.T \\ Department Of Banking Finance And Department Of Business Administration And Management The Federal \\ Polytechnic, Ado-Ekiti,
}

\begin{abstract}
The study investigated the impact of foreign direct investment in Nigeria. The study employs the cointegration ad error correction mechanism to verify the nature of long run and short run relationship between growth of Nigeria and foreign direct investment. The result indicates that foreign direct investment has both long run and short run significant impacts on the growth of Nigeria. However, among all the variables used exchange rate also proved to have a short run significant impact on the growth of Nigeria and the relationship indicates that currency appreciation might not promote the growth of Nigeria at least in the short run. The policy implication is that efforts to stimulate growth of Nigeria through FDI should be supported with exchange rate policy that will make naira to be over-valued as this may squeeze out the tradable sector of the economy.
\end{abstract}

\section{Introduction}

Nigeria as a country, given her natural resource base and large market size qualifies to be a major recipient of FDI in African and linked is one of the top three leading countries that consistently received FDI in the past decade. However the level of FDI attracted by Nigeria is mediocro (Asiedu 2003) compared which resource based and potential need. Further, the empirical linkage between FDI and economic growth in Nigeria is yet unclear, despite numerous studies that have examined the influence of FDI on Nigeria's economic growth with varying outcome (Oseghale and Amonrchienaan 1987; Odoz 1995; Oyinlola, 1995. Adelegan, 2000; Akinlo, 2004). Most of the precious influential study on FDI and growth in sub-Sahara Africa are multi country studies. However, recent evidence affirms that the relationship between FDI and grown may be country and periods specified. Asiedu (2001) submits that the determinants of FDI in one region may not be the same for other different regions. In the same vein, the determinant of FDI in countries within a region may be different from one another and from one period to another.

The results of studies carried out on the linkage between FDI and economic growth in Nigeria are not unanimous of their submission. A close examinations of these pervious studies reveal that conscious efforts was not made to take care of the fact that more than $60 \%$ of the FDI inflows into Nigeria was channelled to attract oil industry. Hence these studies actually modeled the influence of natural resources on Nigeria's economic growth.

In addition the impact of FDI in economic growth is more contentious in empirical than theoretical studies, hence the need to examine the relationship between FDI and grown in different economic dispensation. There is the further problem of endogenity, which has not been consciously tackled in previous studies in Nigeria. FDI may have a positive impact on economic growth leading to an enlarged market size, which in turn attracts further FDI.

However there is an increasing resistance to further liberalization within the economy. This limits the options available to the government to source funds for development purposes and moves the option of seeking FDI much more critical.

Overseas development institute (1997) shows that Nigeria is the second largest FDI recipient and that traditionally, FDI has been concentrated in the extractive industries, but there has been a recent diversification into the manufacturing section which has it 70\% of stock in FDI 1992. But the question is, is it a worthwhile venture when we compare the stock of FDI with it's contribution to the economic growth in the country.

Foreign direct investment now represents a major form of cross boarder resource flow among countries. More than ever before more firms in numerous resource flow among countries. More than ever before, more firms in numerous industries and in many countries are expanding abroad through FDI. The magnitude of FDI within the past few years desires the question as to how far this is necessary to improve investment and economic performance.

Therefore the objective of this study is to empirically investigate the impact of foreign direct investment on the growth of the Nigeria economy. 


\section{Literature Review}

The interest in the subject has also grown out of the substantial increase in FDI flow that started in the late 1990's and led to a wave of research regarding it's determinant.

Thiriwall (1994) referred to foreign direct investment as an investment by multinational companies with headquarters in developed countries. This investment involves not only a transfer of funds (including reinvestment of profit) but also a whole package of physical capital, techniques of production, managerial and marketing expertise, and product advertising and business practices for the maximization of global profits.

IMF'S balance of payment manual defines foreign direct investment as investment made to acquire a lasting interest in a foreign enterprise with the purpose of having an effective voice management. World Bank (1997) observed that both domestic and international structural forces were driving private investment to developing countries since the early 1990's in search of higher returns and opportunities for risk diversification. This has led to the growth of efficiency seeking foreign direct investment inflows through the internal and external deregulation of financial markets.

Feidsteihn (2000) argued that apart from the creation of enabling environment for foreign direct investment in book industrial and developing countries, there are a number of advantages accruing investment inflows, such as:
i. Transfer of technology
ii. Large market
iii. Expand employment e.t.c

Mcdougall (1960) in his own approach considered economic growth resulting from accumulation of factor of production or improvement in technology through foreign direct investment involves a partial equilibrium comparative static approach put in place to examine how marginal increments in investment from abroad are distributed. From his approach, it is believed that inflow of foreign capital, whether in the form of foreign direct investment or portfolio capital will raise the marginal product of capital in the host country. Beyond this, Mcdougall argued that foreign direct investment may be connected to other potentially important benefits.

Hymer (1960) gave another approach that departs from trade theory to the theory of industrial organization. Other contributors include kindle Borger (1969). Vernon (1966) caries (1971), Dunning (1973 and Buckley and Casson (1976) among others. This approach begins with an examination of why firms undertake investment abroad to produce at home. It was argued that for direct investment to thrive, there must be some imperfections in markets for goods and factors, including technology or some interference in competition by government or firms which separates markets.

From the foregoing, it is obivious that foreign direct investment is not only a source of finance and employment but also a medium for acquiring skills, technology, organizational and managerial practices and acess to markets. Thus it is expected to exert a positive impact on growth in the country through the sum of direct and indirect effects of capital inflows along with technology transfer.

Lipsey (1994) illustrated the effect of outward foreign direct investment upon a country's balance of payments and the employment of its works force. He is summed that foreign direct investment trade are substitutes, labour unions and policy makers have long been concerned about the decline in the importance of export as a tool to access foreign markets and the associated loss in employment. However, a number of studies have offered evidence that foreign direct investment and trade may be complements both conceptually and empirically (marksan, 1983, Lipsey and weiss 1981). These studies have shown what differences in technology along countries and growing foreign market can cause foreign direct investment and trade to increase simultaneously. Moreover, firms in the developed countries extend their specific assets including knowledge, human capital and brand names, to produce abroad such that there is no loss in employment.

Lemeius (2000) examined foreign direct investment and trade of the developed countries of fisheries sector using a count data econometric procedure. He analyzed the impact of changes in investment of Japaneses and the U.S. west coast states on this sector in LDCS . He found an increasing level of Japanese investment and the eventual elimination of foreign harvesting and processing of Alaska pollock from U.S controlled water. But data limitations prevented him from obtaining a comparable effect in Alaska (munisamyGopinathpg 4, FDI in food and agricultural sectors.)

\section{Model Specification}

Following Saggi (2002), Rommer (1993), onimodeetal (1983), Barenszteinetal (1989), Eshang (1993), Marthins (2002), Yakubu (2004), Expo (1995). The relationship among the principal variables in this study is presented in simultaneous model that capture the relationship among them. Apart from foreign direct investment which is the key instrument, this study also ascertain the effect of other variables on the economic growth.

$G D P=f(F D I$, Intr, Exr, Exrv $)$

The formulated models for the relationship are

$G D P=\propto_{0}+\propto_{1} F D I+\propto_{2}$ Intr $+\propto_{3}$ Exr $+\propto_{4}$ Exrv $+U_{i}$ 
The appropriate specification of the relationship between the long run theory and short run dynamics within the context of co-integration and error correction has led to important revision in the modeling of macroeconomic relationships and hence dominated most of the time series econometric researchers in recent years Adebiyi (2002).

Therefore, in order to capture the short dynamics properties of the models, the error correction mechanism (ECM) is included in each of them.

Thus the model is modified as follows:

$G D P=\propto_{0}+\propto_{1} F D I+\propto_{2} I n t r+\propto_{3} E x r+\propto_{4} E x r v+E c m_{1}+U_{i} \ldots$ (5)

Where

FDI $=$ foreign Direct investment $($ Total $)$

Intr $=$ interest rate

Exr $=$ Exchange rate

Exrv $=$ External reserve

GDP $=$ Gross Domestic Product

$\alpha_{0}=$ Constant parameter

$\alpha_{1}-\alpha_{4}=$ The coefficient of the independent variables

A test of significance at $5 \%$ level will be conducted on the estimated parameters, using "6" statistics to determine on the extent to which they affect the dependent variables. The extent of Variation in dependent variables would equally be determined for regression equation to know the extent to which the combination of all independent variables have affected the GDP .

The methodology used for this research is conformed to the data available for the purpose of this research work thereby limiting the analyzed data to the period between 1970 to 2007

\section{Result And Discussion}

Discussion of the empirical result will be made here and the findings from the result will be highlighted for the purpose of making relevant conclusions and recommendations.

\section{Unit Root Test}

The unit root test is carried out to know the time series properties of the variables to know if the variables are stationary with respect to time. The Augmented Dickey Fuller test of unit root is used (ADF) where the value of the ADF will be compared with the Mackinnon critical value in absolute terms. The stationarity was determined at $5 \%$ level.

Table 1 ADF Unit Root Test Result

\begin{tabular}{|l|l|l|}
\hline VARIABLES & TEST STATISTICS & ORDER OF INTEGR-ATION \\
\hline GDP & $0.859438^{* *}$ & $1(1)$ \\
\hline EXRV & $-3.450659^{* *}$ & $1(1)$ \\
\hline FDI & $0.708764^{*}$ & $1(1)$ \\
\hline INR & $-6.864013^{*}$ & $1(1)$ \\
\hline EXR & $-3.46554^{* *}$ & $1(1)$ \\
\hline
\end{tabular}

** Significant at $5 \%, *$ significant at $1 \%$

Source: computed output with e-view

The Augmented Dickey fuller (ADF) unit root test on the above table shows that virtually all the variables were non-stationary. Hence all of them were integrated of order one I(1).However, the time series properties exhibited by these variables have created the necessary condition for the co-integration test.

\section{Co-integration Test}

The Johanson co-integration test is employed to determine the number of the co-integration vectors in the models. If the test established at least that one co-integration vector exist among the variables in any of the models under investigation, then a long-run equilibrium relationship exist in the model and this will enable the study to proceed with the error correction model (ECM).

Table 2: Result of Co-integration Test

\begin{tabular}{|l|l|l|l|l|}
\hline $\begin{array}{l}\text { EIGEN } \\
\text { VALUE }\end{array}$ & $\begin{array}{l}\text { LIKELIHOOD } \\
\text { RATIO }\end{array}$ & $\begin{array}{l}\text { 5 PERCENT } \\
\text { CRITICAL VALUE }\end{array}$ & $\begin{array}{l}\text { 1 PERCENT } \\
\text { CRITICAL VALUE }\end{array}$ & $\begin{array}{l}\text { HYPOTHESIZED } \\
\text { NO. OF CE(S) }\end{array}$ \\
\hline 0.999927 & 1308.527 & 233.13 & 247.18 & None ** \\
\hline 0.998698 & 965.8051 & 1929.89 & 204.95 & At most $1^{* *}$ \\
\hline 0.998392 & 726.6225 & 156.00 & 168.36 & At most 2** \\
\hline 0.995838 & 495.0356 & 124.24 & 133.57 & At most 3** \\
\hline 0.951173 & 297.6959 & 94.15 & 103.18 & At most $4 * *$ \\
\hline
\end{tabular}


Assessment Of The Impacts Of Foreign Direct Investment And Interest Rate On The Growth Of

\begin{tabular}{|l|l|l|l|l|}
\hline 0.873310 & 188.9948 & 68.52 & 76.07 & At most 5** \\
\hline 0.865942 & 114.6183 & 47.21 & 54.46 & At most $6^{* *}$ \\
\hline 0.572788 & 42.27677 & 29.68 & 35.65 & At most $7 * *$ \\
\hline 0.222754 & 11.65965 & 15.41 & 20.04 & At most \\
\hline 0.069358 & 2.587704 & 3.76 & 6.65 & At most 9 \\
\hline
\end{tabular}

$*(* *)$ denotes rejection of the hypothesis at $5 \%(1 \%)$ significance level.

L.R. test indicates 8 co-integrating equation (s) at $5 \%$ significance level.

Source: computer output with e-view.

The Johnson co-integration test is employed to determine the number of the co-integration vectors in the models. If the test established at least that one co-integration vector exist among the variables in any of the model under investigation, then a long run equilibrium relationship exist in the model and this will enable the study to proceed with the Error correction model (ECM). The result showed that the test identified cointegration equations at 5\% critical values based on the result that the likelihood ratio is greater than the critical value at 5\%. This shows that GDP, Exvr, FDI, ,INTR and Exr co-integrated in the long run at the same rate by the normalized co-integrating coefficient with the highest log likelihood in absolute term.

Table 3: Long run equation for GDP

\begin{tabular}{|l|l|l|}
\hline Variable & Coefficient & Standard error \\
\hline Constant & 1.267995 & 0.165654 \\
\hline FDI & $0.24619^{*}$ & 0.859491 \\
\hline Intr & -0.41062 & 0.85889 \\
\hline Exr & 0.188 .81 & 0.807 .27 \\
\hline Exrv & 0.664424 & 0.473716 \\
\hline
\end{tabular}

$\mathrm{R}^{2}=0.996842$

Adjusted $\mathrm{R}-$ square $=0.995827$

$\mathrm{DW}=2.018897$

$\mathrm{F}=(982.1433$

The result on table 3 shows that FDI has a positive or direct relationship with the GDP. The coefficient is 0.24619 which indicates that a unit increase in FDI leads to about 24\% rise in the GDP. The result conforms to apriori expectation. Interest rate has an inverse relationship with the GDP but the coefficient is not statistically significant. In addition exchange rate and external reserve both exhibit positive relationship but in the same vein their coefficients are not significant. The implication of the result is that only FDI seems to have long run significant impact on the GDP.

The R square is 0.99 this implies that systemic variation in the GDP is explained by the all the explanatory variables to the tune of about $99 \%$. The $\mathrm{F}$ test which is the test of overall significance indicates that the model is statistically significant. The result showed the Durbin-watson statistics of 2.01 which explained that the model do not suffer from the problem of auto correction.

However, since the result of the co-integration test shows that there exists a long-run relationship exists among the variables. Hence, we move further to the error correction mechanism as a way to establish the shortrun adjustment dynamics.

Table 4.5.1 Parsimonious Error Correction Model.

\begin{tabular}{|l|l|l|}
\hline Variable & Coefficient & Std. error \\
\hline C & 4863.732 & 21516.10 \\
\hline D(GDP(-1) & $0.258376^{* *}$ & 0.193408 \\
\hline D(FDI $(-1)$ & $5.707096^{* *}$ & 5.914911 \\
\hline D(FDI $(-2)$ & 0.7718448 & 0.673969 \\
\hline D(EXRV(2) & -0.807000 & 0.672605 \\
\hline D(EXR(-1) & $0.238033^{* *}$ & 0.125886 \\
\hline D(INTR $(-2)$ & 0.91269 & 0.882025 \\
\hline ECM & $-0.774507^{*}$ & 0.32487 \\
\hline
\end{tabular}

The short run equation indicates that there exists a stronger short run relationship among the variables. The foreign direct investment in particular shows a more signifcant impact. Also some variables that fails to have long run significant impact now has in the short run. For instance the results shows that exchange rate has a short run significant impact on the GDP. The relationship is positive showing that currency depreciation is likely to be an incentive to promote growth in Nigeria.

The Error correction mechanism in the short run adjustment mechanism shows that parsimonious ECM coefficient is -0.774507 which indicate that it was properly signed as the probability values showed that it was perfectly significant. The R-squared also was on the high side of 0.990450 indicating the significance of the model. That is less than $1 \%$ of the variation in the present value of the GDP can only be explained by the error 
terms. The present value of GDP adjusted rapidly to changes in FDI, Exr, Intr and Exrv and that is $77 \%$ of the equilibrium in the dependent variable is corrected in each period.

The value of ECM of -0.774 also implied that about 77 percent of short run inconsistencies are been corrected and incorporated into the long-run relationship, as the speed of adjustment is $77 \%$ denotes that $77 \%$ of any past deviation will be corrected in the currents period as it will take lesser period for any disequilibrium to be corrected.

\section{Conclusion And Recommendations}

The results have shown that FDI has both short run and long run significant impact on the GDP of Nigeria. This indicates that foreign direct investment has been acknowledged as an important source of improving efficiency of the productive sectors of an economy though competition stimulate economic progress, creation of jobs and fostering growth in the host economy. Economics expansion requires continuous investment from foreign sources in order to supplement the inadequate domestic capital, savings and investments in the developing countries like Nigeria.

For foreign direct investment (FDI) to impact on sustainable growth and development, both the public and private sector must pursue corporate social responsibility from the public sector, the creation of competitive economy through economic policies such as deregulation and privatization should be pursued.

In addition, exchange rate has been shown to have a significant impact in the short run. It can be concluded from the study that currency appreciation is likely going to be a dis-incentive to growth in a country like Nigeria. However, it shoul be noted that exchange rate only has a transitory effect on the growth.

In the light of the various revelations in this work, it is important for policy makers to fashion different policy responses to capital inflows, such as foreign direct investment depending on whether such inflows are likely to be sustained or temporary, and against the background of such inflows, carrying the potentials for important improvement in investment in the economy. Effort should be made by the Nigerian government to attract more foreign direct investments to the productive sectors of the economy in a way to increase output level and alleviate poverty in the Nigerian society.

In the process of becoming increasingly integrated with international financial markets, the Nigerian banking system has also become vulnerable to shifts in market confidence. The high domestic interest rate and real exchange rate appreciations have induced banks to borrow abroad to finance both loans and positions in the government money market. Therefore policies to attract more investment (especially FDI) to the economy should revolve around improving the investment climate through macro-economic stability and consistent policies, higher reduced corruption, legal reform reflecting property rights, adequate economic social infrastructure and improvement in security of life and property. In all, the Nigerian government needs to come up with more friendly economic policies and business environment which will attract FDI into virtually all the sectors of the economy.

Finally, the Nigerian government should be able to build investors confidence in all Nigerian economy as lack confidence of investors can be attributed to the low inflow of foreign direct investment in the country.

\section{References}

[1]. Asiedu, E. (2001), “On the Determinants of Foreign Direct Investment toDeveloping Countries: Is Africa Different?", World Development, 30, pp. 107-19

[2]. Asiedu, E. (2003), "Policy Reform and Foreign Direct Investment to Africa: Absolute Progress but Relative Decline", mimeo, Department of Economics, University of Kansas, United States.

[3]. Bukley, P.J and Casson, M.C (1976), "The Future of The Multinational Enterprises”, Macmillan, London.

[4]. Dunning John H. (1981), "Explaining The International Direct Investment Position Of Countries; Towards A dynamic or Developmental Approach" Wettwirtscaftliches, Arc IV Vol 117 pp. 30-64.

[5]. Dunning J.H. (1998), "The changing nature of firms and government in a knowledge based globalizing economy", Centre for International Business Education and Research, Working Paper No. 98007 (Network: Rutgers University).

[6]. Lipsey, R. (2000), “Interpreting Development Countries”, FDI, NBER Word Oloyede J.A. and Obamuyi T.M. (2000),"The Impact of Foreign Direct Investment on the Nigeria Economy" Nigerian Journal of Banking and Financial Issues Vol 3 No. 1. Performance" Journal of Economic Literature, 37(3): 64-111.

[7]. Soludo Charles C. (1988), "Investment in the Growth Process A measure of the Economists Ignorance in Africa. In Rekindling Investment for Economic Development in Nigeria", Ibadan NES.

[8]. UchenduOkorie A. (1993), "Interest Rate policy, Saving and Investment inNigeria", CBN Economic and Financial Review, 31(1).

[9]. United Nations (91969), “Foreign Investment in Developing Countries, UN Development of Economic and Social Affairs.

[10]. Ukeje, S. A. (2003), "Strategies Towards Attracting Foreign Private Investment in Nigeria; A Private Sector view C.B.N. 12th Annual Conference of the Regional Research Unit at Hamdala Hotel Kaduna.

[11]. UNCTAD (1995), World Investment Report, New York and Geneva

[12]. Vernnon, R. (1966),Sovereignty at Bay, The Multinational Spread of Us.enterprises, Basic Books Ltd. New York.

[13]. Vicker S.B. (2002), "Overview of South Africa's Investment Regime and Performance”, Draft Policy Brief, Globallnsight, Issue No. 16, April, Pretoria.

[14]. Vickers S.B. (2003), "Investment Climate Reform in South Africa”, Case Study Commissioned by the Department for International Development, UK. A Contribution to World Development Report 2005 on Investment Climate, Growth and Poverty.

[15]. World Trade Organization (1996), Annual Reports, Trade and Foreign Direct.

[16]. World Bank (2002), World Development Indicators, Washington, D.C.: The World Bank 